\title{
"If you give me some sexing, I might talk to you": researching the Senegalese beach-boys "at my side"
}

\author{
By Emilie Venables (University of Edinburgh)
}

This paper examines some of the difficulties that I encountered during my doctoral fieldwork on aspirations of migration amongst young men and women in Senegal. I discuss how my fieldwork with the beach-boys of the Casamance often led to compromising situations that I had not experienced in other areas of my research. Using one interview in particular, I describe the discomfort and guilt I often felt during my fieldwork, and show how I felt torn between being loyal to myself, my work and my informants. I show how the time I spent carrying out research with the côtéman led to conflict between myself and my other Senegalese friends, who disapproved of my research and the people with whom I spent my time. Rather than this paper being about my research findings, it is about the research process.

Lying on the beach in Cap Skirring in southern Senegal, I shiver as a cloud passes in front of the sun. I stir, squinting, before drifting back into a lazy summer slumber. Then, I hear a sing-song voice which awakens me from my siesta. "Hey, pretty lady! How are you? Ça va les vacances?" My "cloud" had dreadlocks and was wearing patchwork trousers. He was a côtéman, a Senegalese beach-boy about to offer me his services as a guide.

This paper examines some of the difficulties I encountered when carrying out doctoral research on côtéman and their aspirations of transnational migration. I discuss the discomfort I often felt during my research, and how spending time with the so-called "bad guys" on the beach affected relationships with my other Senegalese friends. Using the example of "Ganja", one of my informants, I demonstrate both the awkwardness of one particular interview situation, and how his behaviour gave me an insight into the communication skills and tactics used by côtéman and how these may link to strategies of migration. Ganja is a pseudonym meaning "marijuana". Ganja was the only one of my informants who wanted to remain anonymous, and chose the pseudonym for himself. The word côtéman, meanwhile, is taken from the French word côté, meaning "side", because they are, quite literally, always at the side of tourists! The term remains the same in the singular and plural (personal communication, Lou de Jong, June 2007; see de Jong 2007 for in-depth research on the côtéman).

My fieldwork originally focussed on female sex-workers, but when I realised that there was a link between their work and their desire to leave Senegal and live in Europe, I wondered if men were behaving in a similar way. Who were the so-called coteman who wandered the beaches of the Casamance? What did they do and what were their hopes for the future? Was it true they thought they would get visas through befriending tourists, or was this simply an unfounded rumour? My own encounters with them had only ever been unpleasant, thus I was apprehensive and unsure of 
where my questions would lead me, yet intrigued to discover the stories behind their hassling and whether or not they were linked to an imagined future in Europe.

\section{Background: beach-boys}

Discussions of the link between beach-boys and migration are not new, and although the beaches of the Gambia and more recently Senegal are infamous for their young, dreadlocked men, the phenomenon is not unique to West Africa (de Jong 2007). Ebron makes reference to beach-boys in neighbouring Gambia, whom she refers to as "bumpsters"; young, unemployed men who form part of a "professional friend circuit", hanging around hotels and beaches in search of tourists (Ebron 2002:176, cf. Brown 1992). In addition to the West African beaches of the Gambia and Senegal being known for their côtéman and increased incidences of sex-tourism (both male and female), a similar situation occurs in the islands of the Caribbean. Cabezas, for example, writes about beach-boys in Cuba, whereas others have discussed the use of the label "rent-a-dreads" for the young, beach-bound men who provide both companionship and sexual services to female tourists (Cabezas 2004:1002, de Albuquerque 1998, Pruitt and LaFont 1995). Elsewhere in the Caribbean, such men have been described as "gigolos", and the women who spend time with them "romance tourists" (Brennan 2004, Dahles 1997).

Something that all these words have in common is their negativity: there is very little positive writing about the beach-boys of the world's tourist resorts. Much of the terminology used to describe them has negative connotations and hints of trickery, dishonesty and sexual promiscuity. Although this article makes it obvious that I did not necessarily agree with a lot of the côtéman's actions, or even particularly like some of the men I was spending time with, I try to show that even though their work is not conventional, it is still a way for them to earn a living. It is something of which they are proud, and they want their hassling, I learnt over time, not to be seen as malicious, but to be viewed as a game.

Instead of locating this research within the paradigm of sex-tourism, I argue that through "making contacts" (a phrase used by many of my informants) with both men and women, these young, unemployed men attempt to expand their social networks across international borders in the hope of one day being able to migrate. I was told of men who specifically sought out sexual relationships with older women for this very purpose, but their stories remained in the domain of rumour and gossip, and did not feature in the stories that I collected from the cotéman whose words were at the heart of my fieldwork. I thus hesitate to draw direct comparisons between côtéman and female sex-workers, as men were looking primarily for professional relationships, not romantic and sexual ones.

\section{Who are the côtéman and what do they do?}

Côtéman are easily recognisable, wearing an unofficial, laid-back uniform which sets them apart from those around them. They usually have dreadlocks. When I asked a souvenir seller whom I interviewed why the hairstyle was so popular amongst young men in the tourist trade, he told me "if you want a white girlfriend, you need to have dreadlocks". However, as much as the image of the dreadlocked man fits into the image of the exotic Other sought by many female tourists, côtéman face judgement from wider society for their choice of look. Men working formally in the tourist 
industry shun dreadlocks, feeling that they are inappropriate and a sign of someone who is lazy. (There are also obvious links to religious Baay Fall culture which can be made here - beach-boys are jokingly called "baay faux" in reference to their adoption of certain elements of a religious brotherhood, such as dreadlocks, but not others.) Côtéman are also extremely athletic in physique, their daily beach workouts demonstrating an element of the performative. Long hair is tied back with scarves or bandannas in Rastafarian colours, and jewellery made from beads and shells adorns their necks and wrists. Many wear long, baggy patchwork trousers, or clothes printed in African textiles produced specifically for the tourist market, which feature motifs of djembés or dancing figures on brightly coloured batik backgrounds. Others wear clothes that are Western in style, such as jeans and designer brand name T-shirts and trainers, which are often given as gifts from tourists leaving Senegal. As Schoss (1996) observed during her work with beach-boys in Malindi, although local Kenyans also wore brand names, they did not wear complete, co-ordinated outfits, whereas the beach-boys construct styled, matching outfits for themselves. It is no different in the case of Senegalese beach-boys: the clothes they wear are an example of their future aspirations and a demonstration of their upward social ability, as well as a means of making themselves attractive to Westerners. Obviously, there is some variation amongst the clothes worn by the coteman of the Casamance, and I cannot claim that all men dress in exactly the same way for the same reason, but there are general styles which are adopted, and certain ways in which styles are manipulated and transformed, and it is these which are important (see also de Albuquerque 1998:51).

Côtéman earn a living through offering their services as guides to tourists, usually by waiting outside hotels and restaurants or striking up conversations with people as they walk along the beach. They organise excursions, sell artefacts and arrange local entertainment, such as concerts or drumming workshops, and act as cultural brokers who ease the process of integration for visitors to the region. They form part of the informal economy, and are in competition with trained, registered guides, thus their work is frowned upon by many of those who are formally employed in the tourist industry. The vocabulary they use to describe themselves is interesting: they are "côtéman" amongst themselves, but never in front of tourists. Instead, they talk about themselves as tourist guides, drummers, musicians, entrepreneurs and "antique dealers", aware of the stigmatisation of the term "côtéman" and the negative connotations it has.

However, because of the unofficial nature of their work, and the heavy competition between them to attract clients, their persistence in attracting clients can verge on the offensive. Many female and male tourists complained of being hassled by them, despite the cotéman claiming that they are earning a living and that their work is no more than a harmless game. Although I have never employed a guide in Senegal, official or otherwise, for many people they do provide a useful, genuine service, and I had to constantly remind myself that just because I did not see guides as necessary, others did. Some tourists prefer being accompanied to the local market or restaurants, and they are happy to pay someone to do so, especially as hiring someone acts as a deterrent to other guides and ensures a certain degree of protection throughout one's stay. Côtéman receive financial reward in exchange for their services, as well as meals, transport, cigarettes and drinks, but I argue that the potential long-term benefits of making European connections are often more important to them than the small but immediate financial gain gleaned from their clients. 


\section{Fieldwork and being caught in the middle}

Before beginning to do research with cotéman, I had had very few positive interactions with them, never wanting a guide and resenting their intrusion into my personal space and their assumptions that I was a tourist. I had experienced their verbal abuse, been followed to my campement (a small, basic hotel, usually appealing to backpackers), and had men sit next to me whilst I was sunbathing, but had never had an in-depth discussion with any of them. Suddenly backtracking and having to spend time with the people I had avoided filled me with a sense of dread and panic. I was unsure of how to go about spending time with them, and anxious of the reception I might receive. I had to change my own behaviour and try to forget my preconceptions and past experiences of them. I needed to learn to make eye contact with the men I had avoided, and adapt my body language so as to be neither too hostile nor overly familiar. I did not want to encourage their flirtatious behaviour, yet equally did not want to exclude myself from the group of people I wanted to learn about. I knew that a lot of people appreciated the assistance of a guide, and saw many groups of young backpackers drumming and drinking on the beach with the côtéman in the evenings, therefore realising that there must be reasons for their popularity of which I was yet unaware.

My new research with the côtéman of the Casamance took me to campements, souvenir boutiques, bars and the sandy expanse of beach along which Cap Skirring's wealth was manifested. My interviews led me into an uneasy realm of innuendo and piercing eyes, and suddenly became much more sexual than my previous research with women had been. I talked to souvenir sellers, craftsmen, hotel staff and beachboys in an attempt to piece together the transient and somewhat fragmented lives of those working within the tourist industry. In learning about the lives of male góorgóorlu, the Wolof term for those "getting by" and trying to make the most of their difficult economic circumstances, I was invited into a previously unknown world hazy with hashish and tarnished with a slight sexual sleaziness.

\section{Observing whilst being observed}

Cap Skirring is a small village and beach resort, and gossip spreads quickly and easily within the area, as well as to nearby Ziguinchor and even the neighbouring island of Karabane. I found Cap Skirring to be an isolated place, somehow exempt from the norms and values respected throughout the rest of Senegal, whilst simultaneously being connected both to other towns in Senegal and to Europe. Daily flights from France arrive during the peak tourist season, the recently finished tarmac road connects Cap Skirring with Ziguinchor (the capital of the Casamance region) and the steady influx of tourists brings new flows of material goods, ideas, fashions and migratory aspirations.

Living within what felt, at times, like a strange European microcosm, I was aware of being constantly watched, having my day-to-day appearance judged and my actions and relationships talked about. In addition to the discomfort I felt from the eyes that were directly on me as I carried out interviews, I was equally aware of the gaze of strangers, and knew I was being observed by European tourists and long-term residents as I walked along the beach. I wanted to be able to explain to onlookers that this was work, and that I spent my days sitting on the beach talking to côtéman not in search of a holiday romance or because I had fallen for their tricks, but because of my 
research interests. I knew that I was being observed in the same way that I had observed others, and felt uneasy about the judgements that might be made about me.

Although the gaze of strangers upset me, I was more concerned by how my work and day-to-day routine were affecting relationships with my Senegalese friends. My conversations with Ganja, who I discuss below in more detail, caused friction between one of my close male friends Aziz and myself, and led to the gradual destruction of our friendship. I had known Aziz for several years, and had spent a lot of time with him and his family in the three years I had been visiting Senegal. I trusted and respected him and his family immensely, and they had helped ease the integration process into Senegalese life. Aziz and his family worked in a small campement in Cap Skirring, and he distanced himself from the beach culture of smoking, romancing and drumming as much as possible so as to avoid the reputation and rumours that accompany the lifestyle.

Aziz did not, however, fully approve of my research, or my lifestyle. He did not understand why I needed to spend time with côtéman on the beach after I had been reduced to tears by them, nor could he comprehend how sitting in souvenir boutiques or talking to ambulant traders was "work". He criticised my choice of flip-flops and sarong, and was bemused when I did not dress like the tourists from the larger hotels, feeling that I was letting him down in some way. He warned me about spending time with the "bad guys", telling me I should leave them alone, because of their reputation, and the way they treated women. Despite my protests that they had interesting stories that I wanted to hear, which could be important for my research, I was seen to be putting my reputation at stake and my behaviour was seen to verge on the immoral and unacceptable. In undertaking research with men who had a bad reputation, I too became tainted. I felt forced to choose between two different groups of people - Aziz and his family, my friends and support network, and the côtéman, whom I did not consider to be close friends, but who, along with the social spaces they inhabited, were essential to my work.

\section{New interview dynamics}

In addition to the problems I faced negotiating the blurred area between my research and my private life and the constant feeling of being observed, my research meant that I had to learn to deal with a new way of interviewing and dealing with the occasionally disconcerting behaviour of the cotéman. I noticed a dramatic change in the dynamics of interviews compared to my earlier interviews with women, and realised how any time I spent talking to men who were seen by some locals as social outcasts put my own reputation and my deeply rooted personal relationships at risk.

During my discussions with female sex-workers, men were always the shadowy background figures: they were the absent husbands and unseen clients, unfaithful partners and migrant brothers. They were men that were mentioned but never surfaced. When interviewing côtéman, in addition to talking to men, I was talking to people for whom I originally had very little sympathy, and whose behaviour I initially struggled to understand. Interviews were suddenly rife with sexual tension and I was acutely aware of how what I thought were encouraging gestures could be misinterpreted as flirtation. I no longer placed a reassuring hand on someone's arm as they spoke, and no longer felt comfortable offering my own experiences and stories in exchange for theirs. Questions about my personal life were simple curiosity, but also a 
means of gauging whether or not I was single. As much as I was able to form working relationships with the cotéman, our interactions never became those of friendship. This, I am certain, was mutual. I believe that my informants were as uneasy about forming a friendship with me as I was with them, being unsure of my motives and remembering the initial coldness and suspicion between us. As much as I questioned their behaviour and motives for wanting to befriend me, they doubted mine.

Due to the lack of language barriers, the location and the topic of our discussions, interviewing and talking to men was much easier than I had originally expected, and I felt I achieved more in a week of interviewing them than I had during several months of interviewing women, as the following points demonstrate. Côtéman are able to speak several languages in addition to their first language, which, for the majority, was Wolof or Jola. The Senegalese men I interviewed all had a very high level of French, often with a distinctive accent acquired from spending so much of their time with European tourists. Many also spoke Spanish and Italian, a result of strong diasporic links with Spain and Italy, as well as the abundance of Spanish and Italian tourists during the months of July and August. The Gambian côtéman tended to speak English rather than any other European language, as they spent most of the peak season in the Gambia, where the majority of tourists were English. Our interviews were thus carried out mainly in French or English, with Wolof as the secondary language rather than the main one.

The public location of our interactions also made them practically much easier. When interviewing women I had been dependent upon visiting them in their homes, which was an intrusion for them, and it was also often difficult for me to find where they lived. Côtéman, on the other hand, spent most of their time hanging out in the village of Cap Skirring or on the beach, meaning that I did not have to make home-visits. This also meant that if somebody did not turn up for an interview, I was able to wander along the beach and find someone else to talk to instead.

After their initial suspicions, the majority of my male interviewees were enthusiastic about my research. They laughed at me when I asked if they wanted me to change their names - they had nothing to hide, they told me - why would they want to remain anonymous? I had to stress repeatedly that although my finished thesis would be printed and bound, it was not going to resemble a book as they imagined it, and the level of fame achieved would not be as high as they had hoped. They encouraged me to take photographs of them in their work environment, hoping that my work would act as publicity for their services. They knew that the "tricks of the trade" formed part of my writings, and thus I did not feel I was deceiving them into thinking that everything I was writing was going to be positive.

\section{"Ganja"}

The exception amongst my interviewees was Ganja, a côtéman whose words gave me the title to this article. He differed from the others in his attitudes towards my work, and also in his overtly sexual behaviour. Several months before focusing my research more specifically on côtéman and migration, I had come to Cap Skirring for a weekend break with friends who were visiting me from the UK. We were sunbathing on the beach when Ganja came over, sat down and began to talk to us. He asked us if we were enjoying our holiday and told us that he could take us to a local restaurant and show us around the village. We told him, as politely as we could, that we did not 
want to talk, and that we wanted to be left alone. We turned over and tried to ignore him. He was one of many men to have approached us that day, and our patience was wearing somewhat thin.

He began to tell us, in a mixture of English, French and Wolof, that we were ignorant and ugly and knew nothing about Senegal or how to treat people. He told us that we were in Rome (Cap Skirring), and should behave like the Romans (Senegalese people). Interestingly, this is a view that most people in Cap Skirring's tourist industry do not agree with - they talk about Cap Skirring as a place that is European rather than Senegalese. They see it as a place where they should take on European values in order to integrate and work with tourists, rather than being a place in which tourists should adapt their behaviour. Ganja then accused us of being racist, saying that we should not come to Senegal if we did not want to talk to anyone who was black. I explained to him, in Wolof, that I had lived in Senegal for over a year, was not racist but simply wanted to be left alone. He continued to bombard us with abuse, so in the end we were forced to stand up and leave, listening to him shout obscenities after us as we walked away.

I then avoided Ganja if I saw him on the beach, choosing to stay close to the campement where I knew I would not be hassled or to walk on the beach during the early afternoon, when I knew he would be in the village. One day, however, I was sitting in a friend's restaurant when Ganja walked in. My friend formally introduced us to each other, unaware that we had already met. Ganja's face lit up when he discovered I spoke English, and he began to talk to me, extending his hand and asking me how my holidays were going. I told him that we had already met, and that he had offended both my friends and myself. He looked embarrassed and claimed not to remember, but apologised, saying if he had been rude, it was all part of the game, and that this was the "smiling coast" where I was always welcome. He gave me a necklace and offered me a joint.

Over a period of several months, we began to talk and joke about the first time we met, but I still felt uncomfortable in his presence and tried to avoid being alone with him. Ganja knew that I was interested in hearing about his life, and seemed keen to tell me about it, but was equally curious about the motives behind my research, asking me a stream of questions about my work. I had pieced together parts of his story from the snippets of information he gave me, as well as the stories other people told me about him, but wanted to interview him in more detail before I left the field. He knew that I wanted to talk to him one last time, and purposefully made it difficult for me to do so, even though he had always talked enthusiastically about being interviewed. One afternoon, he called me over as I walked past, and said that he was ready to talk. He said that he would answer my questions, but on his terms. He told me that I was not allowed to take notes in front of him, but that as soon as I went home I could write things down. He told me that I was a clever girl. "I know that you can remember things," he said.

As I sat down, he told me I had sand on my back and that I should turn around so he could brush it off. I told him that it did not matter, that we were on a beach, and that I was used to being sandy. "Turn around," he insisted. "I want to see you. Turn around." I did not turn around, and tried to change the subject, ignoring his hand on my arm. He stared at me throughout our conversation, telling me that he had been with white women before and reassuring me through words and gestures that he was a good lover. "I could have had you that night," he told me. "The night you were in the 
club. I could have had you but I didn't because you were dancing with someone else." Then he offered to talk to me, and give me the information I wanted, in exchange for sex. I politely declined, realising that he was not joking. I attempted to change the subject of conversation, but knew there was no point continuing our discussion. I thanked him, shook his hand and left, feeling his eyes bore into my back as I walked away.

Part of me was intrigued by the conversation, whereas the other part of me wanted to sink into the sand in desperation. I did not feel physically threatened by him, as I was in a very open, public place, but was more stunned and somewhat shocked by his explicitness, as well as being frustrated that another relationship with a male informant had deteriorated. It was not a dangerous situation, just an unpleasant one. Yet, at the same time it was an extremely interesting exchange, and one which gave me great insight into his attitudes towards foreign women. At the same time as realising why women complained about him, I could also see how he was able to seduce them.

Although extreme, Ganja's reaction to my questions showed a desire to assert his authority, and in a sense was a form of power-game. It was also part of his struggle to become connected for the purposes of migration - he used a form of flattery and flirtation I have seen female sex-workers use on male tourists on many occasions, as a technique for "getting connected". He was renowned amongst the other côtéman on the beach for being a "bad boy", and his behaviour during our interview was exactly the kind of behaviour that Aziz had warned me about. Although flirting with tourists was part of the "game" he played, so was simply befriending them. Interactions with côtéman did not have to be sexual, which is why Ganja's behaviour shocked me so much. I had been propositioned and flirted with before, but never in such a direct way. I felt exposed and far from the protection the campement gave me. Although there were sexual overtones in my conversations with other men, this was the most overt and direct exchange I had experienced. When I spoke to other women they told me that they had experienced similar situations, with men flirting with them, or running after them along the beach to ask them if they would like to join them. In as much as this situation was unique, the sexual overtones were not, and they were so extreme in some cases that tourists had made official complaints to the local police.

This situation exemplifies one of the many times I felt the boundaries between my work and personal life were becoming blurred, especially when my informants intruded into my personal space in a way which I found inappropriate. I wanted to maintain a professional, working relationship with my male informants, but found this difficult to do without appearing rude and ungrateful towards those who had given me their time and words. The nature of participant observation means that doing research is a social occasion - I would be talking, drinking and socialising with my informants as I took notes, thus a refusal to give out my phone number or to meet on a regular basis was easily considered impolite, especially in Senegal, where people phone or "beep" each other almost daily to simply say "hello" before hanging up! Another relationship with a male informant, a registered tour guide, became complicated as he phoned me several times a day, or sent me text messages in the middle of the night telling me he had "feelings for me". I eventually had to cut contact with him, and no longer answered his phone calls, as he refused to believe my insistence that his feelings were not returned. 
I felt guilty in cutting contact with people whom I had spent time interviewing, but equally knew that if giving out my phone number led to calls at 1am and daily text messages with proclamations of love, a professional relationship would be hard to maintain. I did not want to lie to the people with whom I spent most of my time, so did not create a fictional husband for myself as other researchers had suggested, but instead was vague about the details of my private life and avoided giving out my mobile number if possible. I also set up a separate email address which I gave to my informants to allow myself to distinguish between work and outside-work communications. Small, practical steps such as these enabled me to manage my research and keep some distance between my social and professional relationships.

Throughout my time in the field I suspected that some of the men I interviewed and spent time with had ulterior motives in wanting to talk to me, but Ganja had made his very clear. His direct offer was more than an invite to his house to drink attaya (local tea, and an important social ritual) or to meet his family, and was much more overtly sexual than other men's flirtations. I, and many other female researchers I met whilst in the field were used to answering endless questions about our home countries and life in Europe and the United States, and male attention was something we were used to and learnt to cope with, for the most part. For Ganja, however, I was not simply a source of information about the West, or another European contact; I was someone with whom he claimed to want a sexual encounter.

Meeting and forming friendships or relationships with Europeans who may be able to provide the opportunity to work or live elsewhere is an important part of the côtéman's work. As well as being a potential migratory link, tourists are also a source of material benefit. The men I interviewed proudly talked about the phone calls they received from friends in France, the packages of new clothes sent to them from Italian acquaintances and the Spanish friends they had made. Their address books were important to them, and during interviews, they would reach into their bags to show me ageing collections of letters and photographs sent to them by European friends. Côtéman all talk about their friends, or friends of friends, who have "made it" to Europe, and these success stories are clung to in the belief that one day they too will succeed and be able to "escape". Côtéman are in competition with each other to expand their social networks, thus I began to understand their persistence in relation to their desperate desire to migrate, rather than simply dismissing it as an unwanted annoyance. They seek to form professional and romantic relationships with tourists as a way of expanding their social networks to include Europe, and in order to do so, often play along to the stereotypical image expected of them, whether through the clothes they wear, the music they listen to or the places in which they socialise.

\section{Conclusion}

I have thus discussed some of the difficulties I faced during my fieldwork in Senegal, and have shown how the researcher can easily find him- or herself in a compromising position. When doing fieldwork, especially intense participant observation, boundaries between work and non-work are fluid and overlapping, and in order to participate, the researcher may have to compromise their beliefs and be exposed to a certain degree of risk, whether physical, emotional or socio-political. From my (maybe over-cautious) reluctance to give out my phone number or respond to amorous text messages, the small boundaries I created around myself prevented me from becoming fully immersed into the lives of those I was studying, and offered me 
a certain degree of privacy and safety. In refusing the "sexing" and some parts of the cotéman lifestyle that were offered to me, I did not collect as much data as I could have done, and was required to make a choice between leaving my own comfort zone and compromising myself, or remaining in it and compromising my research. I eventually realised that I could not live like my informants, and that in distancing myself from their night-time activities and avoiding the spaces that I felt uneasy in, I, like my informants, found a balance between the two.

In having had many negative experiences with côtéman, I began my research with an element of bias, and in writing up, I do not want to offend or betray the people I worked with, but equally want to tell their stories and share what I saw. Throughout my time in the field I found myself sympathising with them, seeing them as young, unemployed men seeking a way of making money. I began to understand that their persistence was annoying yet usually harmless, and saw instead the pride they took in showing people around the region. I do not want my words to offend them, and made sure that they were aware of what I was writing about, but equally I do not want to disguise the persistence and annoyance of their "game", because it is symptomatic of their desperation to leave a country which they believe has very few prospects to offer.

\section{References}

Brennan, Denise. 2004. What's love got to do with it? Transnational desires and sex tourism in the Dominican Republic. Durham, NC and London: Duke University Press.

Brown, Naomi. 1992. Beachboys as cultural brokers in Bakau Town, the Gambia. Community Development Journal 27(4), 361-370.

Cabezas, Amalia L. 2004. Between love and money: Sex, tourism, and citizenship in Cuba and the Dominican Republic. Signs: Journal of Women in Culture and Society 29(4), 987-1015.

Dahles, Heidi. 1997. The new gigolo: Globalization, tourism and changing gender identities. Focaal: Tijdschrift voor Antropologie, Special issue: Globalization/localization: Paradoxes of Cultural Identity 30/31, 121-138.

De Albuquerque, Klaus. 1998. In search of the Big Bamboo. Transition 77, 48-57.

De Jong, Lou. 2007. “We plakken als vliegen, maar steken niet als muggen”: Ontmoetingen tussen côtéman en toeristen in Senegal ["We stick like flies, but do not sting like mosquitoes": Encounters between côtéman and tourists in Senegal]. Amsterdam: Aksant.

Ebron, Paulla A. 2002. Performing Africa. Princeton and Oxford: Princeton University Press.

Pruitt, Deborah and Suzanne LaFont. 1995. Love and money: Romance tourism in Jamaica. Annals of Tourism Research 22(2), 422-440.

Schoss, Johanna. 1996. Dressed to "shine": Work, leisure and style in Malindi, Kenya. In Clothing and difference: Embodied identities in colonial and postcolonial Africa (ed.) H. Hendrickson, 157-188. Durham, NC and London: Duke University Press. 


\section{Acknowledgments}

Thanks must go to Lou de Jong, who first made me aware of the côtéman of Cap Skirring through her own research, and who was extremely helpful throughout my fieldwork. Thanks must also go to my supervisors Prof. Patricia Jeffery and Prof. Paul Nugent for reading early drafts of this article. This research was funded by the ESRC.

\section{About the author}

Emilie Venables recently submitted her $\mathrm{PhD}$ at the Centre of African Studies at the University of Edinburgh. Her research focused on aspirations of migration in Senegal, and she has looked at how sexuality, internet dating and illegal pirogue departures have been used as migration strategies by young Senegalese men and women. She is currently a senior researcher at the Reproductive Health and HIV Research Unit (RHRU) in Johannesburg. She can be contacted on evenables@,rhru.co.za 